\title{
Women Empowerment Perspective of Tourism Development at Idanre Hills, Ondo State, Nigeria
}

\author{
AROWOSAFE, F C; *TUNDE-AJAYI, O A; RAFIU, O S \\ Department of Ecotourism and Wildlife Management, Federal University of Technology, Akure, Nigeria \\ *Corresponding Author Email: tunde-ajayioa@futa.edu.ng
}

\begin{abstract}
Tourism has established new opportunities for the female gender through generating and propagating independence and income, particularly in developing countries and rural communities. This study identifies socio-demographic characteristics, employment status and women empowerment initiatives at Idanre Hills, Ondo State, Nigeria. The study employed the use of structured questionnaire targeted randomly at 120 women residents of Idanre community. Data collected was analyzed using SPSS version 21 and results were presented descriptively; through charts, percentage tables and inferentially; through chi square. Results indicated that majority of the women are within age group of 36-45 years (36.7\%) and have secondary education (50.8\%). Also, highest percentage of the women are not employed by the ministry of tourism $(89.2 \%)$ while majority of the women employed are cleaners $(46.67 \%)$. The women are majorly basic food sellers $(38.3 \%)$ at the tourism destination and this forms their role in tourism activities there. Furthermore, there is a significant relationship between employment status and socio-demographic characteristics of the women $(p<0.05)$. Women are presently under-utilized and underempowered and should be involved more in core tourism activities at Idanre Hills.
\end{abstract}

\section{DOI: https://dx.doi.org/10.4314/jasem.v24i7.9}

Copyright: Copyright $($ C 2020 Arowosafe et al. This is an open access article distributed under the Creative Commons Attribution License (CCL), which permits unrestricted use, distribution, and reproduction in any medium, provided the original work is properly cited.

Dates: Received: 16 May 2020; Revised: 29 June 2020; Accepted: 07 July 2020

Keywords: Employment, Empowerment, Gender, Tourism, Women.

Tourism has recorded a very great and significant impact on all forms of nations worldwide; whether developed, developing or under-developed. Underdeveloped economies have focused on their socioeconomic improvement through their investment and commitment to tourism in order to create employment and business avenues, export returns and infrastructural development (World Tourism Organization, 2016). In many of these less developed countries, tourism has emerged as a tool to greatly drive and improve their economies, replacing ancient or deteriorating sectors such as agriculture (Pratt and Harrison, 2015). Furthermore, tourism offers opportunity for poverty eradication in the poor and rural communities of these less developed countries (Scheyyens and Russell, 2012). It has also been affirmed that tourism has established new opportunities for the female gender through generating and propagating independence and income, particularly in developing countries and rural communities (Annes and Wright, 2015).

Emphasis on the importance of gender issues to tourism has been made clear over the years based on the worldwide attention that gender equality and female gender empowerment has received by prominent organizations and initiatives like the United Nations World Tourism Organization (UNWTO) and the third Millennium Development Goal (MDG3) (Ferguson and Alarcon, 2014).

No means can effectively demonstrate that women empowerment has entered the realms of the most popular and fast growing worldwide industry than the United Nations World Tourism Organization (UNWTO)'s plan to involve women empowerment among its 'triple commitment' objectives to the Millennium Development goals (UNWTO, 2011). As the fastest and rapidly growing global industry, tourism has shown effectiveness in making great contributions as well as being at the fore-front of women empowerment initiatives. For instance, Ong (2009) showed how tourism which greatly involves and thrives on social entrepreneurship, can effectively function as the avenue to create opportunities for women.

In the past three decades, there has been a conspicuous increase in studies about women, gender leisure as well as tourism (Henderson and Gibson, 2013). This can be attributed to the 'cultural turn' from the two core disciplines of geography and sociology 
(Aitchison, 2005). Aitchison further states that in the late 1970s, there was a growing trend of feminist research in the field of leisure studies, which grew rapidly. Ever since then, there has been an improvement in researches of gender identities, roles and relationships in tourism development (Tran and Walter, 2014).Tourism has been widely known to cause direct merits to community members through employment creation thereby providing the families in the communities with source of income and livelihood (Movono, 2012). In many developing countries, women account for almost $50 \%$ or more of the employees in the tourism industry (World Tourism Organization, 2011).

Indeed, the importance of women in tourism cannot be overemphasized. Various studies have observed the roles of the female gender in the industry, not excluding the economic and socio-cultural impacts these roles play in their livelihoods (Gibson, 2001). However, only few studies have studied and observed the effect of tourism employment on women empowerment (Annes and Wright, 2015; Ferguson, 2011; Knight and Cottrell, 2016). This study thus aimed to investigate the impact of tourism on women empowerment in Idanre Hills, Ondo State, Nigeria.

\section{MATERIALS AND METHOD}

This study was carried out at Idanre Hills also known as Oke Idanre located in Idanre town in Ondo State of southwestern Nigeria. Idanre falls on latitude $9^{0} 81$ north of the equator and longitude $5^{0} 51$ east of the Greenwich meridian. The data collection instrument for this study was a structured, self-administered questionnaire designed in English, since English is the official language in Nigeria. A total of 120 copies of questionnaire were distributed randomly to the visitors of the site which were all filled and returned during data collection. The questionnaire was divided into two sections. The first section captured the sociodemographic information of the respondents while the second section captured women empowerment program offered at the site. The data collected were analyzed through the use of SPSS 21 and were presented descriptively using percentage tables, charts and inferentially using chi square.

\section{RESULTS AND DISCUSSION}

Table 1 presents the socio-demographic characteristics of the respondents. Highest percentage of the respondents (36.7\%) were within 36-45 years of age which is an active and a youthful age and this age range could also explain why most of the respondents were married $(70 \%)$ and had around 3-4 children $(35.8 \%)$. This shows that they are matured enough to work and fully cater for their family which is in line with assertion that labour force participation rate is the proportion of the population ages 15 and older that is economically active, that is, everybody who supply labour for the manufacture of goods and services during a specified period (The World Bank, 2012). Also, majority of the respondents were Christians $(70 \%)$ and had secondary education level $(50.8 \%)$ as opposed to tertiary education for higher employment standards in the country.

\begin{tabular}{lll}
\multicolumn{3}{c}{ Table 1: Socio demographic characteristics } \\
\hline Variables & Frequency $\mathbf{~ ( N = 1 2 0 )}$ & Percentage (\%) \\
\hline Age & 29 & 24.2 \\
18-25 years & 28 & 23.3 \\
26-35 years & 44 & 36.7 \\
36-45 years & 15 & 12.5 \\
46-55 years & 4 & 3.3 \\
Above 55 years & & \\
Marital Status & 28 & 23.3 \\
Single & 84 & 70.0 \\
Married & 3 & 2.5 \\
Divorced & 5 & 4.2 \\
Separated & & \\
Number of Children & 21 & 17.5 \\
0 kids & 34 & 28.3 \\
1-2 kids & 43 & 35.8 \\
3-4 kids & 22 & 18.3 \\
5-10 kids & & \\
Educational Background & 13 & 10.8 \\
No formal Education & 31 & 25.8 \\
Primary Education & 61 & 50.8 \\
Secondary Education & 15 & 12.5 \\
Tertiary Education & & 70 \\
Religion & 84 & 22.5 \\
Christianity & 27 & 7.5 \\
Islam & 9 & \\
Others & & \\
\hline
\end{tabular}


Their low level of education would limit empowerment and it could also be attributed to some belief system that it is better to train male children as supported by Kabeer (2005) who noted that education limits empowerment, especially in societies conditioned by traditional and cultural practices while also providing an example of where women's role is purely to produce offspring; their access to education is therefore diminished by various cultural practices. Findings revealed that highest percentage of the respondents $(89.2 \%)$ were not employed by the ministry of tourism at the site (Figure 1). This shows a great gender imbalance in the industry and connotes that the industry prefers the male gender to females at Idanre Hills. This clearly indicates that the women do not have the required employment representation in the industry to strike a gender balance let alone be effectively represented in the leadership cadre of the tourism sector at Idanre and is supported by UNWTO (2011) that despite developing and improving tourism industry opportunities by numbers, and the obvious "diversity merit" this brings, women are continually underrepresented in senior and general management positions and when it comes to women in leadership roles, the tourism sector falls short of other industries that don't demonstrate similar benefit.

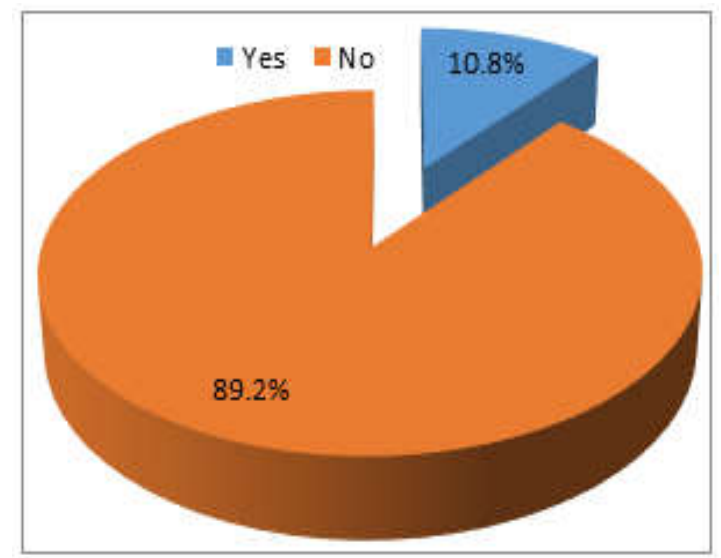

Fig 1: Employment rate by ministry of tourism at Idanre Hills

Findings also revealed that out of the few employed by the ministry of tourism at the site, majority are employed as cleaners (46.67\%) which is a menial job and belongs to the low income grade which depicts that the male gender accounts for the high income grade of employment in the ministry and shows a high level of gender imbalance (Figure 2). This is in line with Bibi (2017) who stated that the roles being held by women are the lowest level of the employment ladder and are attributed to the minimal entry level of qualifications such roles require; a feature which many rural women were suited for since the majority of them did not have specific skills, credentials or higher education levels. This low and menial form of employment shows gender imbalance and goes a long way to put the female gender at risk of low standard of living and other accompanying risks as supported by Baum (2013) that unskilled or semi-skilled women tend to work in the most vulnerable jobs, where they are more likely to experience poor working conditions, inequality of opportunity and treatment, violence, exploitation, stress and sexual harassment.

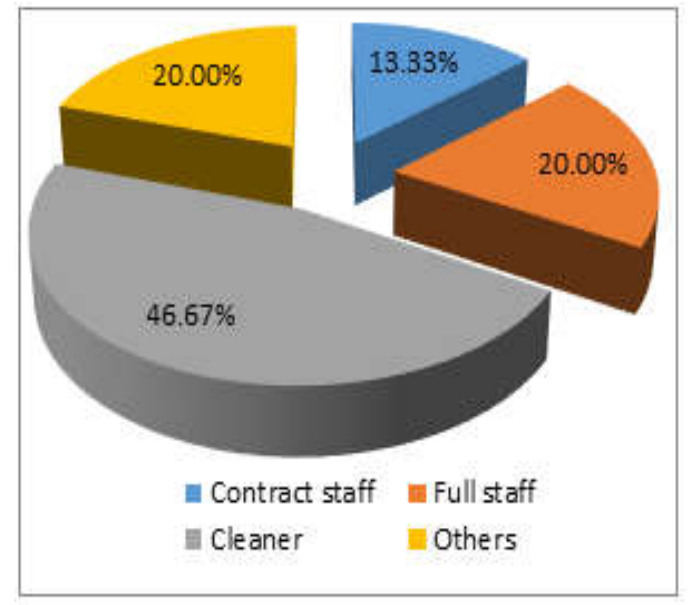

Fig 2: Capacity of employed women at Idanre Hills

Table 2 reveals the roles of women in tourism activities at the site and reveals that majority of the women at the site were involved in basic need sales (38.3\%) Idanre Hills which is not one of the basic sectors of tourism industry at the site. Findings also reveal that the women had no role $(37.5 \%)$ in tourism activities at the area. This shows women have been sidelined in tourism activities apart from being underemployed at Idanre Hills. Though the entrepreneurship sector seems insignificant due to its size and the calibre of unskilled or semi-skilled people involved, it is an integral part of the success of tourism at tourism destination sites. Women should be encouraged to take up businesses relating to tourism and incentives should be given to them to help them achieve growth in their businesses as there have been results of women recording success in their businesses as recorded by Ferguson (2010) that women produce clothing and crafts for sale to tourists in Guatemala, and in Nepal, women set up tea houses for hiking tourists (McMillan et al., 2011). In Fiji, women have established small hair braiding and handicraft stalls to cater for tourists who are accommodated in hotels close to villages (Movono et al., 2015). Providing more business atmosphere for women will also reduce the pressure of direct employment in the tourism industry and provide alternative livelihood to the women. UNWTO (2011) revealed that despite the fact that women have been in charge of enterprises in some parts of the world for at 
least thirty years, it has only been from the 1990s on that women's entrepreneurship has grown and become more visible. Direct and indirect involvement in tourism industry through employment and entrepreneurship also brings about other advantages as stated by Nwosu (2014) that with the different levels of educational background women have, through skills training, they are able to up-skill themselves, such as: enabling them to speak a different language; acquire a new skill, such as hospitality skills; and being able to engage in entrepreneurial ventures. The chi square test of relationship between socio-demographic characteristics of the women and their employment status revealed that Age $(p=0.000)$, marital status $(p=0.000)$, number of children $(p=0.000)$, education $(\mathrm{p}=0.000)$ and religion $(\mathrm{p}=0.044)$ all had significant relationship with the women's employment status (Table 3).

Table 2: Role in tourism activities

\begin{tabular}{lll}
\hline Variables & Frequency(N=120) & Percentage (\%) \\
\hline No role & 45 & 37.5 \\
Tour guide & 6 & 5.0 \\
Transport provider & 6 & 5.0 \\
Food seller & 11 & 9.2 \\
Accommodation & 4 & 3.3 \\
Basic need seller & 46 & 38.3 \\
Restaurant & 2 & 1.7 \\
Total & 120 & 100.0 \\
\hline
\end{tabular}

Table 3: Relationship between socio-demographic characteristics and employment status

\begin{tabular}{llll}
\hline Variables & Chi square $\left(\chi^{2}\right)$ value & Sig. & Decision \\
\hline Age & 45.749 & 0.000 & $*$ \\
Marital status & 47.904 & 0.000 & $*$ \\
Number of children & 46.287 & 0.000 & $*$ \\
Education & 36.463 & 0.000 & $*$ \\
Religion & 6.248 & 0.044 & $*$ \\
\hline \multicolumn{4}{c}{$P<0.05$, Keys: ${ }^{*}$-significant, NS-Not significant }
\end{tabular}

Conclusion: Findings from this study revealed that women are not adequately employed and represented in the tourism industry at Idanre Hills, Nigeria. Women have been given limited access to the running of the tourism business and empowerment generation for them is low. This study has thus provided baseline data of the sectors in which women are underrepresented and provided ways in which human resources can be effectively utilized through more inclusion of women in different sectors of the tourism industry so as to improve the success of the tourism industry.

\section{REFERENCES}

Aitchison, C (2005). Feminist and gender perspective in tourism studies. Tour. Studies, 5(3), 207-224.

Annes, A; Wright, W (2015). 'Creating a room of one's own': French farm women, agritourism and the pursuit of empowerment. Women's Studies International Forum, 53, 1- 11

Baum, C (2013). Employee Tenure and Economic Losses in Wrongful Termination Cases. $J$. Forensic Econs. : April 2013, Vol. 24, No. 1, 4166.

Bibi, PM (2017). Tourism, Indigenous women and empowerment: A case study of Taveuni, Fiji.
Ferguson, L (2010). Tourism as a Development Strategy in Central America: exploring the impact on women's lives. Retrieved from http://centralamerica.myzen.co.uk/assets/Tourism $\% 20$ as $\% 20 a \% 20$ development $\% 20$ strategyFINAL . pdf

Ferguson, L (2011). Promoting gender equality and empowering women? Tourism and the third Millennium Development Goal. Cur. Issues in Tour. 14(3), 235-249

Ferguson, L; Alarcón, DM (2014). Gender and sustainable tourism: reflections on theory and practice. J. Sustainable Tour. 23(3), 401-416

Gibson, H (2001). Gender in tourism: Theoretical perspectives. Women as producers and consumers of tourism in developing regions, 19-43

Henderson, KA; Gibson, HJ (2013). An integrative review of women, gender, and leisure increasing complexities. J. Leis. Res., 45(2), 115-135

Kabeer, N (2005). Gender equality and women's empowerment: a critical analysis of the third Millennium Development Goal. Gender and Dev., 13(1), 13-24. 
Knight, DW; Cottrell, SP (2016). Evaluating tourismlinked empowerment in Cuzco, Peru. Annals of Tour. Res., 56, 32-47

McMillan, CL; O'Gorman, KD; MacLaren, AC (2011). A vehicle for the sustainable empowerment of Nepali women. Int. J. Cont. Hosp. Mgt., 23(2), 189-208.

Movono, A (2012). Tourism's impact on communal development in Fiji: A case study of the socioeconomic impacts of The Warwick Resort and Spa and The Naviti Resort on the indigenous Fijian villages of Votua and Votualalai. (Unpublished Masters Thesis). The University of the South Pacific, Suva..

Movono, A; Pratt, S; Harrison, D (2015). Adapting and reacting to tourism development: a tale of two villages on Fiji's Coral Coast. In S. Pratt \& D. Harrison (Eds.), Tourism in Pacific Islands: current issues and future challenges. Oxford: Routledge.

Nwosu, B (2014). Hospitality education: sustainable empowerment opportunities for Nigerian women. W. Hosp. and Tour. Themes, 6(1), 62-76.

Ong, ST (2009). Women Empowerment through Tourism- From Social Entrepreneurship Perspective. Accessed October 4, 2010 at http://edepot.wur.nl/11305
Pratt, S; Harrison, D (Eds.). (2015). Tourism in Pacific Islands: current issues and future challenges. Oxford: Routledge.

Scheyvens, R; Russell, M (2012). Tourism and poverty alleviation in Fiji: comparing the impacts of small and large-scale tourism enterprises. $J$. Sustainable Tour. 20(3), 417-436.

The World Bank (2012). World development indicators. Retrieved from The World Bank; 2012. Available:http://data.worldbank.org/datacatalog/w orld-development-indicators

Tran, L; Walter, P (2014). Ecotourism, gender and development in northern Vietnam. Annals of Tour. Res., 44(0), 116-130.

UNWTO (201). Tourism Highlights 2011 Edition. Retrieved on 12/ 03/2015 http://mkt.unwto.org/sites/all/files/docpdf/u nwtohighlights11enhr.pdf

World Tourism Organization. (2011). Global report on Women in Tourism 2010. Retrieved October 27, 2014, from http://www.eunwto.org/doi/pdf/10.18111/9789284413737

World Tourism Organization. (2016). UNWTO Tourism Highlights Madrid, Spain: World Tourism Organization. 